\title{
Review
}

\section{p53 and the Viral Connection: Back into the Future $\ddagger$}

\author{
Ronit Aloni-Grinstein ${ }^{1,2,+}$, Meital Charni-Natan ${ }^{1,+}$, Hilla Solomon ${ }^{1}$ and Varda Rotter ${ }^{1, *}$ \\ 1 Department of Molecular Cell Biology, Weizmann Institute of Science, 76100 Rehovot, Israel; \\ ronitag@iidr.gov.il (R.A.-G.); meital.charni@weizmann.ac.il (M.C.-N.); \\ hilla.besserglick@weizmann.ac.il (H.S.) \\ 2 Department of Biochemistry and Molecular Genetics, Israel Institute for Biological Research, Box 19, \\ 74100 Ness-Ziona, Israel \\ * Correspondence: varda.rotter@weizmann.ac.il; Tel.: +972-8-9344501; Fax: +972-8-9342398 \\ + These authors contributed equally to this work. \\ $\ddagger$ This review is dedicated to the 25th memorial year of Prof. Yosef Aloni of the Weizmann Institute of Science, \\ for his seminal and important pioneering research in the field of molecular biology of the SV40 virus.
}

Received: 15 May 2018; Accepted: 1 June 2018; Published: 4 June 2018

\begin{abstract}
The discovery of the tumor suppressor p53, through its interactions with proteins of tumor-promoting viruses, paved the way to the understanding of p53 roles in tumor virology. Over the years, accumulating data suggest that WTp53 is involved in the viral life cycle of non-tumor-promoting viruses as well. These include the influenza virus, smallpox and vaccinia viruses, the Zika virus, West Nile virus, Japanese encephalitis virus, Human Immunodeficiency Virus Type 1, Human herpes simplex virus-1, and more. Viruses have learned to manipulate WTp53 through different strategies to improve their replication and spreading in a stage-specific, bidirectional way. While some viruses require active WTp53 for efficient viral replication, others require reduction/inhibition of WTp53 activity. A better understanding of WTp53 functionality in viral life may offer new future clinical approaches, based on WTp53 manipulation, for viral infections.
\end{abstract}

Keywords: virus; p53; cancer; SV40; papilloma; zika; influenza; HIV-1; HSV-1; vaccinia

\section{Introduction}

Almost 40 years ago, while studying tumor induction by small DNA tumor viruses, several groups have "bumped" into a nonviral protein with an apparent molecular mass of 53KDa, which co-immunoprecipitated with Simian Vacuolating Virus 40 (SV40) large T-antigen protein [1-5]. This host protein was also identified in most of the retrovirus Abelson Murine Leukemia Virus (A-MuLV) infected transformed cells [6]. The question of whether p53 is an oncogene or a tumor suppressor was for many years an enigma. Finally, it was understood that WTp53 is a tumor suppressor gene, which was crowned as the "guardian of the genome" [7], while the mutant p53 is a bona fide oncogene [8].

Indeed, WTp53 is a well-known tumor suppressor protein, which is activated by varied stress signals. When activated, WTp53 regulates various cellular pathways that determine the cell fate, such as cell cycle arrest, differentiation, senescence, and apoptosis $[7,9,10]$. As viral infection evokes cellular stress, it is not surprising that infected cells harbor stabilized activated WTp53 [11]. Consequently, to gain successful replication and spreading, viruses use different strategies to handle their host cells and manipulate WTp53's guardian role. Different viral families have evolved protein binding motifs and other mechanisms to either hijack or interfere with WTp53 functions. For example, in order to spread, some viruses cause WTp53-mediated cell death of the host cell by different mechanisms such as cell lysis and various types of programmed cell death (e.g., apoptosis). On the other hand, some viruses can cause cells to proliferate by attenuating WTp53 function and by that may seed the 
onset of cancer development [12]. Of note, it is well established that in addition to the interaction of p53 with viruses, cancer is also associated with the direct mutation of the p53 gene. Indeed, p53 is mutated in more than $50 \%$ of human tumors. Most of the common p53 mutations gained an oncogenic function rather than just being a dysfunctional tumor suppressor gene $[8,13]$.

In this review, we discuss the different viral strategies used to modulate the p53 defensive responses.

\section{Tumor-Promoting Viruses}

\subsection{SV40 and Adenoviruses}

The small DNA viruses, Adenoviruses and SV40, utilize the DNA replication machinery of the host cell by elegant and diverse strategies. In the host cell, transcription regulation of cell cycle genes is achieved by the binding of the Retinoblastoma protein $(\mathrm{Rb})$ to the transcription factor E2F. Apparently, both Adenoviruses and SV40 are able to manipulate the host cell by the binding of their viral proteins, E1A and SV40 T-antigen, to the Rb, respectively [14-19]. This binding releases $\mathrm{Rb}$ from E2F, leading to E2F transcriptional activation that mediates S phase entrance. p53, as the "guardian of the genome", senses this aberrant $S$ phase movement and acts to induce apoptosis. However, to eliminate p53 activity, the viral T-antigen or the adenovirus E1B proteins bind p53 and by that inactivate it [20], allowing the progression into the $S$ phase [9].

Another association between SV40 and p53 is noticed on the transcription level. Studies suggested that T-antigen uses "DNA mimicry" [9]; T-antigen contains p53 elements that are able to bind to p53 and by that prevent p53 transcriptional regulation, leading to transformation of the host cell [21]. Indeed, all examined T-antigen mutants that were no longer able to bind p53 lost their ability to transform the infected cells [22]. Moreover, this association of p53 with SV40 not only attenuates p53 normal functions, but also exerts a "helper" function for SV40 prosperity. This helper function is provided by WTp53 through its TAD1 domain, which bridges the interactions of p53 with various transcriptional promoting proteins such as histone acetyltransferase p300 and CBP, thus providing SV40 with additional transcriptional potential [23].

Drayman et al. provided another view on the relationship between p53 and SV40. Interestingly, immediately after SV40 infection, activated p53 is noticed only in cells that do not express SV40 viral proteins, suggesting a p53-dependent decision between abortive and productive infection. These p53 host defense mechanisms did not rely on apoptosis, cell cycle arrest, or induction of interferon-stimulated genes, but rather on binding competition between p53 and Sp1, a host protein, which is essential for SV40 assembly [24,25].

\subsection{Papilloma}

The human papilloma viruses (HPVs) are double-stranded DNA viruses with over 60 identified types, which are divided by their oncogenic capacity into two groups, high-risk and low-risk HPVs. While low-risk HPVs are associated with benign hyperplasia, high-risk HPVs contain 12 known virus types that are associated with anogenital carcinomas. Although the majority of cervical cancer cases are caused by the high-risk HPV-16 and HPV-18 infections, other cancer types are also associated with high-risk HPVs such as head and neck, mouth, vulva, vagina, penis, and anus cancers [26,27]. In order to induce viral replication in the infected cells, the HPV takes advantage of its viral proteins E6 and E7 that inhibit the p53 and pRb tumor suppressor proteins activity, respectively. Hence, the HPV interferes with the normal host cell cycle and leads to malignant transformation [28,29]. The viral E6 protein abuses the host protein-degradation machinery by interactions with its E3 ubiquitin ligase, E6AP, which in turn directly mediates the degradation of p53 by $26 \mathrm{~S}$ proteasome, leading to low levels of p53 in the infected cells. Accordingly, E6 proteins of low-risk HPV types, such as HPV-6 and HPV-11, are incapable of degrading p53 efficiently [30-32], thus leading to a benign phenotype. 
In addition, recent accumulated data have shown that not only E6 but also the viral protein E7 are able to affect p53 function by their binding to the DREAM complex. p53 regulates the DREAM complex in order to inhibit the expression of plethora of genes. It was found that E7 is able to associate directly with DREAM components p107 and p130, leading to disruption in p53 regulation [33,34]. Taken together, it seems that both the E6 and E7 proteins of HPV interfere with p53 regulation and cause changes in the host cell cycle, resulting in unregulated cell divisions and emission from apoptosis.

\section{Nononcogenic Viruses}

\subsection{Poxviruses}

The smallpox and vaccinia viruses, which are members of the poxviruses family, have a large DNA of $191 \mathrm{~kb}$ [35], thus the replication of their viral DNA in the host cell is likely to be a major burden. The B1R kinase is an early viral gene required for vaccinia virus DNA synthesis and replication. B1R was found to hyperphosphorylate p53 in several residues in the N-terminal transactivation domain, including Ser15 and Thr18, in an MDM2-dependent manner, leading to an increase in p53 ubiquitination and degradation. Moreover, the presence of B1R significantly reduced the acetylation of p53 by p300, reducing p53 stability [36]. This mechanism of p53 downregulation was suggested to allow DNA synthesis of poxviruses, such as observed in cells infected with vaccinia virus [37]. Another poxvirus that uses this mechanism is the Tanapoxvirus (TPV), a member of the Yatapoxvirus genus [38]. Infection in humans results in a febrile illness, characterized by the formation of a few small, papular lesions that ulcerate but heal rapidly within a few weeks. The open reading frame of the TPV142R shares significant amino acid homology to the B1R kinase and is also capable of phosphorylating p53 and reducing its expression [39]. Accordingly, by mediating p53 destabilization, the B1R and TPV142R proteins allow the vaccinia and TPV viruses to proliferate and prosper inside infected cells.

\subsection{Flavivirus}

The Zika virus (ZIKV) is a mosquito-borne, single-stranded, positive-sense RNA virus belonging to the genus Flavivirus in the family Flaviviridae, originally identified in Uganda in 1947 [40] and which has spread in Latin America, mainly in Brazil [41]. ZIKV infection in pregnant women was suggested to be associated with the increasing incident of congenital microcephaly (CM) observed since 2015 [41-43]. ZIKV infection, as other risk factors including rare genetic disorders or environmental factors such as hypoxia, drugs, or various pathogens, affect the normal neural progenitors expansion, differentiation, and the survival of their progeny. This in turn may lead to reduction in the final number of brain cells and to CM [44]. The mechanisms underlying these biological processes are still obscure. In an attempt to reveal the key factors mediating this phenotype, the gene expression profile of induced pluripotent stem cell derived from human neural progenitors cells (hNPC) infected with ZIKV was compared with the profiles of developing neural tissues obtained from three severe genetic microcephaly models. The study revealed that a signature of p53 regulation is common to ZIKV and to the microcephaly models. This signature consists of antiproliferative and pro-apoptotic p53-related responses. Moreover, it was shown that ZIKV-infected hNPCs are characterized by genotoxic stress, p53 activation, and apoptotic cell death [45]. In another study, a database of 248 ZIKV-related proteins in the human genome and 221 microcephaly-associated human proteins was used to predict their shared molecular mechanisms. Interestingly, p53 was found to possess a central role in the genetic regulatory network of apoptosis and cell death pathways in both ZIKV infection and microcephaly. This reported apoptosis of neural cells is most likely the core for neuronal defects and CM caused upon infection with ZIKV. The suggested mechanism underlying this p53 activation is the binding of the ZIKV capsid protein (ZCP) to p53 E3 ligase, MDM2, thus preventing the formation of the MDM2-p53 complex. In that manner, the ZIKV leads to elevated p53 protein levels and its activation, triggering the apoptosis of neural cells [46]. 
The West Nile virus, which may cause different severe morbidities and even death [47], is another member of the Flaviridae family which can also elevate p53 levels during its infection process. The West Nile viral capsid protein interacts with MDM2 and sends it to the nucleolus, thus preventing its binding to $\mathrm{p} 53$ and leading to $\mathrm{p} 53$ stabilization. The stabilized p53 activates Bax protein that in turn mediates apoptosis [48].

\subsection{Influenza A Virus}

Influenza A virus (IAV) is a member of the Orthomyxovirdae family of RNA viruses and the primary cause of respiratory tract infections [49]. IAV is a cytolytic virus that induces apoptosis, presumably to improve the efficiency of its replication [50,51]. Indeed, the accumulation and activation of p53 in IAV-infected cells is essential for apoptosis [52,53]. To obtain p53 stabilization, the viral nucleoprotein (NP) impairs the interaction between p53 and MDM2, leading to p53 stability and transcriptional activity [54]. In addition, others reported that NP interacts with the host protein RING finger protein 43 (RNF43), an E3 ubiquitin ligase, in order to modulate p53 ubiquitination levels, leading to p53 stabilization and enhanced apoptosis [55]. Both in vitro and in vivo experiments show correlation between p53 absence and survival of IAV infected cells. For example, reduction of p53 activity in cell culture inhibited IAV-induced cell death; in addition, mouse embryo fibroblasts isolated from p53 knockout mice, infected with IAV, exhibited augmented levels of survival in comparison to wild-type p53 mouse embryo fibroblasts [52]. It seems that IAV hijacks p53 by causing its activation, leading to enhanced apoptosis and thus IAV viral replication. However, ample data suggest that p53 also acts as a host antiviral factor that enhances innate and adaptive immune responses in order to battle the infection. For example, IAV infection of p53-deficient mice resulted in increased mortality, severe weight loss, and increased viral load in their lungs compared with WT p53 counterparts. Indeed, a comparative analysis of the global expression profiles of IAV-infected p53K/O and p53WT mice suggested an impaired interferon-mediated immune response against IAV infection in the absence of p53. Moreover, a comparison of cytokine and chemokine expression levels between IAV-infected p53K/O and p53WT mice implies a dysregulated cytokine and pro-inflammatory chemokine response in the absence of p53 [56]. In agreement with the latter study, knockdown of p53 expression by RNAi enhanced IAV replication and reduced the expression of antiviral type I interferon-stimulated genes (ISGs), such as IRF7, IRF9, ISG15, ISG20, GBP1, RIG1, and OAS1 [57]. Another study showed that p53 serves as a host antiviral factor that enhances innate and adaptive immune responses to IAV. Indeed, lungs of WT p53 mice that were infected with IAV exhibited lower levels of IAV viral load in comparison to lungs of $\mathrm{p} 53 \mathrm{~K} / \mathrm{O}$ mice. Interestingly, the massive leukocyte infiltration into $\mathrm{p} 53 \mathrm{~K} / \mathrm{O}$ mice lungs was observed only in a later phase of infection and was accompanied by a severe necrosis of the bronchial epithelium [58]. Furthermore, p53 absence was associated with defective IAV-specific T-cell immunity. Wang et al. showed that upon influenza virus infection, p53 is activated, leading to elevation of its target gene, endoplasmic reticulum aminopeptidase 1 (ERAP1), which is a regulator of the Major Histocompatibility Complex I (MHCI) expression. Appropriate regulation of MHC expression is important for protection against viral infection [59]. These data propose a role for p53 in the Cytotoxic T lymphocytes MHC1-dependent response [60]. Taken together, these findings suggest that the absence of p53 leads to delayed innate response, which impairs the ability to clear the virus from the lungs. This may cause severe IAV-induced morbidity observed in the p53K/O mice. All in all, it seems that IVA induces p53 accumulation in a biphasic pattern, first at the beginning phase of infection, immediately after the virus absorption, leading to an innate response, and at the middle-late phase of infection at the apoptotic phase [53].

\subsection{The Human Immunodeficiency Virus Type 1}

The human immunodeficiency virus type 1 (HIV-1) is a lentivirus (a subgroup of retrovirus) which causes a progressive loss in CD4 lymphocyte numbers and function, resulting in the immunodeficiency associated with AIDS [61]. Various HIV-1 proteins were shown to interact with the host WTp53 
during the process of infection, and thus to either attenuate or activate it, depending on infection stage. In early phase, HIV-1 proteins such as Nef and HIV-1 LTR were suggested to inactivate p53. The viral protein Nef, for example, interacts directly with p53 via its $\mathrm{N}$ terminus. This interaction results in the destabilization of p53, thereby decreasing p53 transcriptional activity and apoptosis [62]. Moreover, the upstream elements of the HIV-1 LTR, including the nuclear factor kappa B (NF-KB) binding sites, decrease the p53 inhibitory effects on viral transcription [63]. In later stages, other HIV-1 proteins were suggested to induce p53 activity, supporting HIV-1 prosperity. For example, Tat inhibits the host protein SIRT1, and by that removes SIRT1 inhibition on p53. This activates p53 to induce the expression of its target genes, $p 21$ and BAX, leading to host cells' death [64]. Additionally, the viral protein, Vif, affects p53 stability by blocking the MDM2- p53 interactions. This mediates a G2 arrest, which positively supports HIV-1 replication [65]. Interestingly, positive regulatory loops are suggested. It was shown that overexpression of WTp53 decreases the activation level of the HIV-1 LTR via the viral protein, Vpr [66]. Additionally, Mukerjee et al. have shown that overexpression of WTp53 mediates inhibition of the transcriptional elongation HIV-1 LTR via phosphorylation of RNA polymerase II [67]. This HIV-1 LTR attenuation in turn might lead to further p53 activation.

\subsection{The Human Herpes Simplex Virus 1}

The human herpes simplex virus-1 (HSV-1) genome is a linear double-stranded DNA virus [68]. Accumulated data have shown that p53 plays a dual role in HSV-1 replication at different stages of its infection [69]. On one hand, p53 supports HSV-1 replication by inducing the expression of the viral protein ICP27 that is essential for the HSV-1 replication at early stages of the infection [69]. This positive p53 regulation was also corroborated in in vivo experiments, where higher HSV-1 replication and mortality rates were noticed in p53WT mice compared with their p53KO counterparts [70]. On the other hand, p53 mediates the degradation of the viral protein ICP0, which is also essential for both viral replication and a host immune response repression, and by that attenuates HSV-1 replication [69]. In addition, p53 responsive elements (RE) were shown to reside adjacent to different viral immediate-early (IE) genes, such as ICP4 and ICP8, which are critical for the HSV-1 life cycle [71]. By that, it is suggested that p53 inhibits the expression of these genes and HSV-1 replication, thus providing insight into the negative impact of p53 on the expression of vital HSV-1 functions and replication [72]. Interestingly, HSV-1 manages to antagonize this negative impact of p53 via the viral protein ICP22, which is able to bind p53 directly and abolish its function [69].

\section{Targeting WTp53 as a Future Clinical Approach for Viral Infections}

p53 regulation was found to play a crucial role in different infection stages of various viruses. Therefore, it is rational to believe that novel treatments, based on targeting and reactivating p53, may lead to beneficial therapeutic outcomes not only for cancer therapy but also for infectious diseases at large. Indeed, super p53 mice, harboring an extra copy of p53, showed better tumor resistance as well as antiviral activity [73]. Accordingly, some preliminary proof of concept experiments have shown that p53 may serve as a therapeutic target for viral infections. For example, p53 activation and induction of p53-dependent apoptosis may function as such antiviral therapy. Recently, a treatment for HPV head and neck squamous cell carcinoma (HNSCC), which involves the use of 5-Azacytidine (5-aza), was suggested. It was found that by mediating DNA demethylation in host cells, 5-aza led to several outcomes; on the one hand, it reduced the expression of HPV genes and on the other hand, it caused p53 protein stabilization that in turn induced p53-dependent apoptosis [74]. Others have shown that treatment with anticancer chemotherapeutic agents, such as 5-fluorouracil (5-FU), can be used also against HIV-1 latently-infected T-cells, since 5-FU also stabilizes p53 leading to increased levels of p53-dependent apoptosis [75].

All in all, it seems that the incessant effort for developing drugs that will be able to target and activate WTp53, such as Nutlin, is crucial not only for cancer therapy but also to a greater extent for different antiviral infections. 


\section{Conclusions}

Viruses are dependent on their cellular host for their prosperity, thus they have adopted different strategies to recruit the host cell machinery for their own needs. p53, being an important cellular transcription factor, orchestrates main cellular pathways which determine the cell fate. Therefore, it is not surprising that WTp53 is a prominent candidate for viral targets (Table 1). Viruses may target p53 in different modes. While some viruses need active p53, others dysregulate p53 in order to proliferate. Interestingly, some viruses act in a stage-specific dual manner regarding p53 regulation, activating at some stages of the viral cycle and inhibiting in others (Figure 1, Table 2). Despite the opposing viral strategies, each virus benefits according to its biological identity. Overall, tumor-promoting viruses reduce p53 activity or use p53 not in its "classical" functions. On the other hand, non-tumor-promoting viruses generally use p53 in its classical functions in order to proliferate and spread. WTp53 is known to participate in the innate immunity response to viral infection. p53 promotes and regulates the expression of the type I IFN response, as well as the induction and modulation of various cytokines and macrophage function [76,77]. Therefore, it is still an intriguing open question how viruses that activate the WTp53 overcome the normal classical function of WTp53 as a host defense player.

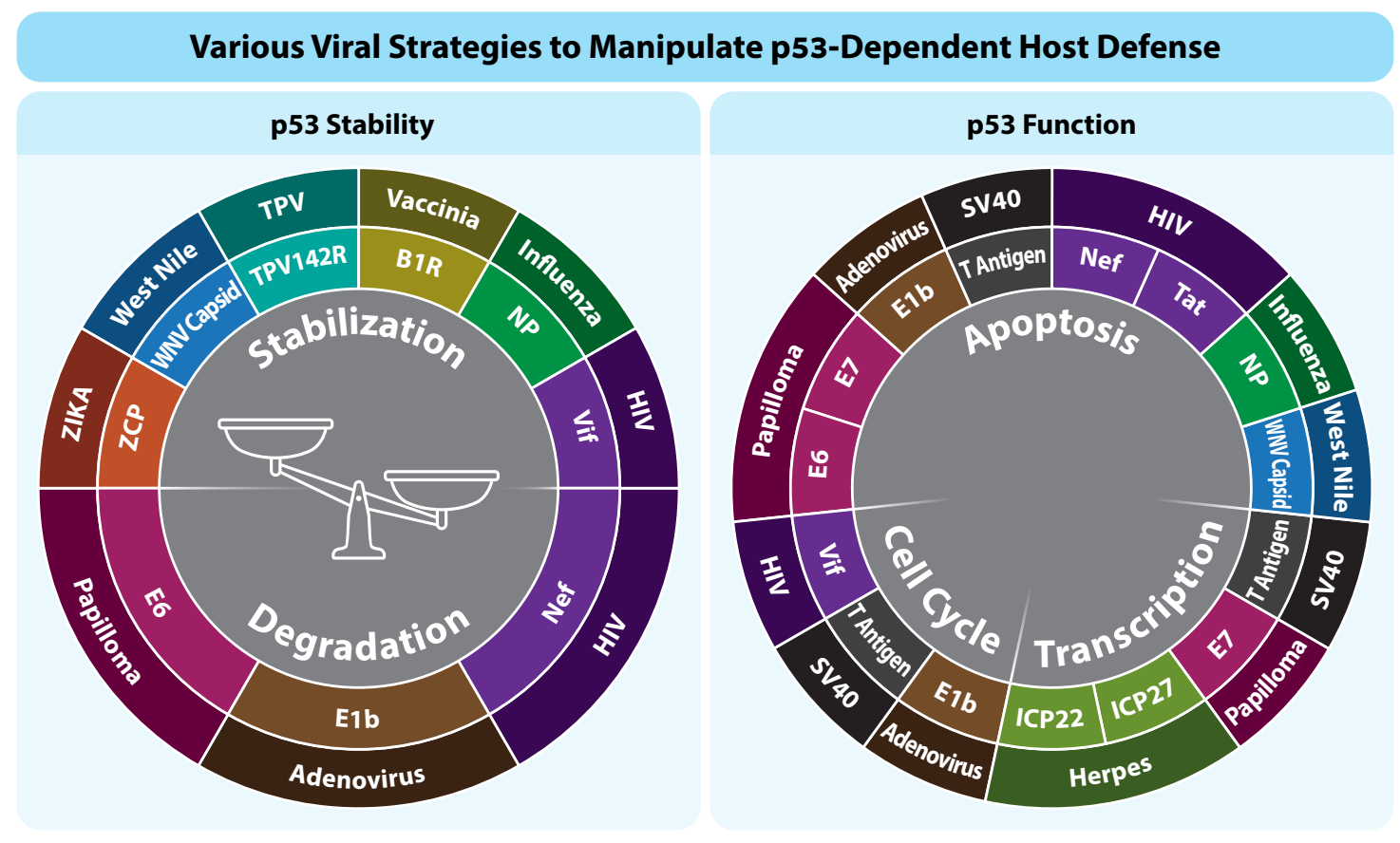

Figure 1. Various viral strategies to manipulate p53-depndent host defense.

Table 1. Various viral proteins and their interactions with p53.

\begin{tabular}{|c|c|c|c|c|}
\hline Virus & Viral Protein & Interaction with p53/Influencing p53 & Outcome & Ref. \\
\hline SV40 & T-antigen & Binds to $\mathrm{p} 53$ & $\begin{array}{l}\text { p53 bridges the interaction } \\
\text { between p300/CBP and } \\
\text { T-antigen Allows progression } \\
\text { to } S \text { phase }\end{array}$ & {$[20,23]$} \\
\hline Adenovirus & E1B & Binds to p53 & Allows progression to $S$ phase & [20] \\
\hline Papilloma virus & $\begin{array}{l}\text { 1. E6 } \\
\text { 2. E7 }\end{array}$ & $\begin{array}{l}\text { 1. Interacts with E3 ubiquitin } \\
\text { ligase, E6AP } \\
\text { 2. Connects directly with DREAM } \\
\text { components p107 and p } 130\end{array}$ & $\begin{array}{l}\text { 1. Degradation of } p 53 \\
\text { 2. Disruption in p53 regulation }\end{array}$ & $\begin{array}{c}{[28]} \\
{[33,34]}\end{array}$ \\
\hline
\end{tabular}


Table 1. Cont.

\begin{tabular}{|c|c|c|c|c|}
\hline Virus & Viral Protein & Interaction with p53/Influencing p53 & Outcome & Ref. \\
\hline Vaccinia virus & B1R kinase & $\begin{array}{l}\text { Hyperphosphorylation of p53, significant } \\
\text { reduction in the acetylation of p53 } \\
\text { by p300 }\end{array}$ & $\begin{array}{l}\text { Increase in p } 53 \text { ubiquitination } \\
\text { and stability }\end{array}$ & {$[36,37]$} \\
\hline Tanapoxvirus & TPV142R & Phosphorylation of p53 & To be determined & [39] \\
\hline ZIKA virus & $\begin{array}{l}\text { C-terminus of the } \\
\text { ZIKA capsid } \\
\text { protein }(\mathrm{ZCP})\end{array}$ & $\begin{array}{l}\text { Interacts with MDM2 and interferes with } \\
\text { the formation of MDM2 and p53 complex }\end{array}$ & High levels of activated p53 & [46] \\
\hline West Nile virus & WNV capsid & $\begin{array}{l}\text { Interferes with the formation of the } \\
\text { HDM } 2 \text { and p } 53 \text { complex }\end{array}$ & $\begin{array}{l}\text { Stabilization of p53 and the } \\
\text { subsequent induction of its } \\
\text { target apoptotic protein, Bax. }\end{array}$ & [48] \\
\hline Influenza virus & $\begin{array}{l}\text { viral nucleoprotein } \\
\text { (NP) }\end{array}$ & $\begin{array}{l}\text { 1. Association of NP with p53 } \\
\text { 2. NP interacts with the host protein } \\
\text { RING finger protein } 43 \text {, a RING-type E3 } \\
\text { ubiquitin ligase }\end{array}$ & $\begin{array}{l}\text { 1. Impairs the } \\
\text { Mdm2-mediated p53 } \\
\text { ubiquination and the } \\
\text { interaction between p53 } \\
\text { and Mdm2 } \\
\text { 2. Modulates p53 } \\
\text { ubiquitination levels, leading } \\
\text { to p53 stabilization and } \\
\text { enhanced apoptosis }\end{array}$ & {$[54,55]$} \\
\hline $\begin{array}{l}\text { Human } \\
\text { immuno-deficiency } \\
\text { virus type } 1\end{array}$ & $\begin{array}{l}\text { 1. Nef } \\
\text { 2. Tat } \\
\text { 3. Vif }\end{array}$ & $\begin{array}{l}\text { 1. Direct interaction with p53 } \\
\text { 2. Inhibition of SIRT1 } \\
\text { 3. Blocks MDM2-mediated degradation } \\
\text { and nuclear export of p53 }\end{array}$ & $\begin{array}{l}\text { 1. Destabilization of p53 } \\
\text { 2. Activation of p53 pathway } \\
\text { (p21 and Bax) } \\
\text { 3. G2 arrest }\end{array}$ & $\begin{array}{l}{[62]} \\
{[64]} \\
{[65]}\end{array}$ \\
\hline $\begin{array}{l}\text { Human herpes } \\
\text { simplex virus-1 }\end{array}$ & $\begin{array}{l}\text { 1. ICP22 } \\
\text { 2. ICP27 }\end{array}$ & $\begin{array}{l}\text { 1. Interacts with p53 } \\
\text { 2. p53 induces its expression }\end{array}$ & $\begin{array}{l}\text { 1. Antagonizes the } \\
\text { p53-dependent degradation of } \\
\text { the viral protein ICP0. } \\
\text { 2. HSV-1 replication }\end{array}$ & [69] \\
\hline
\end{tabular}

Table 2. Characterization of p53/virus interactions.

\begin{tabular}{ccc}
\hline $\begin{array}{c}\text { Viruses that Require } \\
\text { Reduction/Inhibition of p53 }\end{array}$ & $\begin{array}{c}\text { Viruses that Require both Activation and } \\
\text { Reduction of p53 during Infection, } \\
\text { in a Stage-Dependent Manner }\end{array}$ & $\begin{array}{c}\text { Viruses that Require } \\
\text { Activation of p53 }\end{array}$ \\
\hline Adenovirus [9,20] & SV40 [24] & Zika [46] \\
Vaccinia [36] & Influenza A virus [56-58] & West Nile [48] \\
Tanapoxvirus [39] & HIV-1 [62] & \\
Human papillomavirus [28,33,34] & HSV-1 [70] & \\
\hline
\end{tabular}

Author Contributions: R.A.-G., M.C.-N. took the lead in writing the manuscript. H.S. edited and advised the writing. V.R. supervised and edited the writing. All authors provided critical feedback and helped shape the manuscript.

Funding: This publication was funded by the Center of Excellence from Flight Attendant Medical Research Institute (FAMRI) and from the Israel Science Foundation (ISF). This publication reflects the authors' views and not necessarily those of the European Community.

Acknowledgments: V.R. is the incumbent of the Norman and Helen Asher Professorial Chair Cancer Research at the Weizmann institute.

Conflicts of Interest: The authors declare no conflict of interest.

\section{References}

1. Lane, D.P.; Crawford, L.V. T antigen is bound to a host protein in SV40-transformed cells. Nature 1979, 278, 261-263. [CrossRef] [PubMed]

2. Linzer, D.I.; Levine, A.J. Characterization of a $54 \mathrm{~K}$ dalton cellular SV40 tumor antigen present in SV40-transformed cells and uninfected embryonal carcinoma cells. Cell 1979, 17, 43-52. [CrossRef]

3. Kress, M.; May, E.; Cassingena, R.; May, P. Simian virus 40-transformed cells express new species of proteins precipitable by anti-simian virus 40 tumor serum. J. Virol. 1979, 31, 472-483. [PubMed] 
4. Melero, J.A.; Stitt, D.T.; Mangel, W.F.; Carroll, R.B. Identification of new polypeptide species (48-55K) immunoprecipitable by antiserum to purified large T antigen and present in SV40-infected and -transformed cells. Virology 1979, 93, 466-480. [CrossRef]

5. Smith, A.E.; Smith, R.; Paucha, E. Characterization of different tumor antigens present in cells transformed by simian virus 40. Cell 1979, 18, 335-346. [CrossRef]

6. Rotter, V.; Witte, O.N.; Coffman, R.; Baltimore, D. Abelson murine leukemia virus-induced tumors elicit antibodies against a host cell protein, P50. J. Virol. 1980, 36, 547-555. [PubMed]

7. Lane, D.P. Cancer. p53, guardian of the genome. Nature 1992, 358, 15-16. [CrossRef] [PubMed]

8. Brosh, R.; Rotter, V. When mutants gain new powers: News from the mutant p53 field. Nat. Rev. Cancer 2009, 9, 701-713. [CrossRef] [PubMed]

9. Levine, A.J.; Oren, M. The first 30 years of p53: Growing ever more complex. Nat. Rev. Cancer 2009, 9, 749-758. [CrossRef] [PubMed]

10. Vogelstein, B.; Lane, D.; Levine, A.J. Surfing the p53 network. Nature 2000, 408, 307-310. [CrossRef] [PubMed]

11. Sato, Y.; Tsurumi, T. Genome guardian p53 and viral infections. Rev. Med. Virol. 2013, 23, 213-220. [CrossRef] [PubMed]

12. Kaminskyy, V.; Zhivotovsky, B. To kill or be killed: How viruses interact with the cell death machinery. J. Intern. Med. 2010, 267, 473-482. [CrossRef] [PubMed]

13. Oren, M.; Rotter, V. Mutant p53 gain-of-function in cancer. Cold Spring Harb. Perspect. Biol. 2010, 2 , a001107. [CrossRef] [PubMed]

14. May, E.; May, P.; Weil, R. Analysis of the events leading to SV40-induced chromosome replication and mitosis in primary mouse kidney cell cultures. Proc. Natl. Acad. Sci. USA 1971, 68, 1208-1211. [CrossRef] [PubMed]

15. DeCaprio, J.A.; Ludlow, J.W.; Figge, J.; Shew, J.Y.; Huang, C.M.; Lee, W.H.; Marsilio, E.; Paucha, E.; Livingston, D.M. SV40 large tumor antigen forms a specific complex with the product of the retinoblastoma susceptibility gene. Cell 1988, 54, 275-283. [CrossRef]

16. Shirodkar, S.; Ewen, M.; DeCaprio, J.A.; Morgan, J.; Livingston, D.M.; Chittenden, T. The transcription factor E2F interacts with the retinoblastoma product and a p107-cyclin A complex in a cell cycle-regulated manner. Cell 1992, 68, 157-166. [CrossRef]

17. Weinberg, R.A. The retinoblastoma protein and cell cycle control. Cell 1995, 81, 323-330. [CrossRef]

18. Whyte, P.; Buchkovich, K.J.; Horowitz, J.M.; Friend, S.H.; Raybuck, M.; Weinberg, R.A.; Harlow, E. Association between an oncogene and an anti-oncogene: The adenovirus E1A proteins bind to the retinoblastoma gene product. Nature 1988, 334, 124-129. [CrossRef] [PubMed]

19. Peeper, D.S.; Zantema, A. Adenovirus-E1A proteins transform cells by sequestering regulatory proteins. Mol. Biol. Rep. 1993, 17, 197-207. [CrossRef] [PubMed]

20. Sarnow, P.; Ho, Y.S.; Williams, J.; Levine, A.J. Adenovirus E1b-58kd tumor antigen and SV40 large tumor antigen are physically associated with the same $54 \mathrm{kd}$ cellular protein in transformed cells. Cell 1982, 28, 387-394. [CrossRef]

21. Liu, X.; Marmorstein, R. When viral oncoprotein meets tumor suppressor: A structural view. Genes Dev. 2006, 20, 2332-2337. [CrossRef] [PubMed]

22. Zhu, J.Y.; Abate, M.; Rice, P.W.; Cole, C.N. The ability of simian virus 40 large T antigen to immortalize primary mouse embryo fibroblasts cosegregates with its ability to bind to p53. J. Virol. 1991, 65, 6872-6880. [PubMed]

23. Hermannstadter, A.; Ziegler, C.; Kuhl, M.; Deppert, W.; Tolstonog, G.V. Wild-type p53 enhances efficiency of simian virus 40 large-T-antigen-induced cellular transformation. J. Virol. 2009, 83, 10106-10118. [CrossRef] [PubMed]

24. Drayman, N.; Ben-Nun-Shaul, O.; Butin-Israeli, V.; Srivastava, R.; Rubinstein, A.M.; Mock, C.S.; Elyada, E.; Ben-Neriah, Y.; Lahav, G.; Oppenheim, A. p53 elevation in human cells halt SV40 infection by inhibiting T-ag expression. Oncotarget 2016, 7, 52643-52660. [CrossRef] [PubMed]

25. Gordon-Shaag, A.; Ben-Nun-Shaul, O.; Roitman, V.; Yosef, Y.; Oppenheim, A. Cellular transcription factor Sp1 recruits simian virus 40 capsid proteins to the viral packaging signal, ses. J. Virol. 2002, 76, 5915-5924. [CrossRef] [PubMed]

26. Park, I.U.; Introcaso, C.; Dunne, E.F. Human Papillomavirus and Genital Warts: A Review of the Evidence for the 2015 Centers for Disease Control and Prevention Sexually Transmitted Diseases Treatment Guidelines. Clin. Infect. Dis. 2015, 61 (Suppl. 8), S849-S855. [CrossRef] [PubMed] 
27. De Villiers, E.M. Heterogeneity of the human papillomavirus group. J. Virol. 1989, 63, 4898-4903. [PubMed]

28. Koromilas, A.E.; Li, S.; Matlashewski, G. Control of interferon signaling in human papillomavirus infection. Cytokine Growth Factor Rev. 2001, 12, 157-170. [CrossRef]

29. Zur Hausen, H. Papillomavirus and p53. Nature 1998, 393, 217. [CrossRef] [PubMed]

30. Crook, T.; Tidy, J.A.; Vousden, K.H. Degradation of p53 can be targeted by HPV E6 sequences distinct from those required for p53 binding and trans-activation. Cell 1991, 67, 547-556. [CrossRef]

31. Elbel, M.; Carl, S.; Spaderna, S.; Iftner, T. A comparative analysis of the interactions of the E6 proteins from cutaneous and genital papillomaviruses with p53 and E6AP in correlation to their transforming potential. Virology 1997, 239, 132-149. [CrossRef] [PubMed]

32. Scheffner, M.; Huibregtse, J.M.; Vierstra, R.D.; Howley, P.M. The HPV-16 E6 and E6-AP complex functions as a ubiquitin-protein ligase in the ubiquitination of p53. Cell 1993, 75, 495-505. [CrossRef]

33. Engeland, K. Cell cycle arrest through indirect transcriptional repression by p53: I have a DREAM. Cell Death Differ. 2018, 25, 114-132. [CrossRef] [PubMed]

34. Fischer, M.; Uxa, S.; Stanko, C.; Magin, T.M.; Engeland, K. Human papilloma virus E7 oncoprotein abrogates the p53-p21-DREAM pathway. Sci. Rep. 2017, 7, 2603. [CrossRef] [PubMed]

35. Moss, B. Regulation of vaccinia virus transcription. Annu. Rev. Biochem. 1990, 59, 661-688. [CrossRef] [PubMed]

36. Santos, C.R.; Vega, F.M.; Blanco, S.; Barcia, R.; Lazo, P.A. The vaccinia virus B1R kinase induces p53 downregulation by an Mdm2-dependent mechanism. Virology 2004, 328, 254-265. [CrossRef] [PubMed]

37. Wali, A.; Strayer, D.S. Infection with vaccinia virus alters regulation of cell cycle progression. DNA Cell Biol. 1999, 18, 837-843. [CrossRef] [PubMed]

38. Downie, A.W.; Taylor-Robinson, C.H.; Caunt, A.E.; Nelson, G.S.; Manson-Bahr, P.E.; Matthews, T.C. Tanapox: A new disease caused by a pox virus. Br. Med. J. 1971, 1, 363-368. [CrossRef] [PubMed]

39. Seibert, K.N.; Essani, K.; Bejcek, B.E. The Tanapoxvirus 142R Protein is a Serine-Threonine Kinase that Phosphorylates the Tumor Suppressor p53. Open Virol. J. 2013, 7, 1-4. [CrossRef] [PubMed]

40. Dick, G.W.; Kitchen, S.F.; Haddow, A.J. Zika virus. I. Isolations and serological specificity. Trans. R. Soc. Trop. Med. Hyg. 1952, 46, 509-520. [CrossRef]

41. Calvet, G.; Aguiar, R.S.; Melo, A.S.O.; Sampaio, S.A.; de Filippis, I.; Fabri, A.; Araujo, E.S.M.; de Sequeira, P.C.; de Mendonca, M.C.L.; de Oliveira, L.; et al. Detection and sequencing of Zika virus from amniotic fluid of fetuses with microcephaly in Brazil: A case study. Lancet Infect. Dis. 2016, 16, 653-660. [CrossRef]

42. Gabriel, E.; Ramani, A.; Karow, U.; Gottardo, M.; Natarajan, K.; Gooi, L.M.; Goranci-Buzhala, G.; Krut, O.; Peters, F.; Nikolic, M.; et al. Recent Zika Virus Isolates Induce Premature Differentiation of Neural Progenitors in Human Brain Organoids. Cell Stem Cell 2017, 20, 397-406. [CrossRef] [PubMed]

43. Cauchemez, S.; Besnard, M.; Bompard, P.; Dub, T.; Guillemette-Artur, P.; Eyrolle-Guignot, D.; Salje, H.; Van Kerkhove, M.D.; Abadie, V.; Garel, C.; et al. Association between Zika virus and microcephaly in French Polynesia, 2013-15: A retrospective study. Lancet 2016, 387, 2125-2132. [CrossRef]

44. Abuelo, D. Microcephaly syndromes. Semin. Pediatr. Neurol. 2007, 14, 118-127. [CrossRef] [PubMed]

45. Ghouzzi, V.E.; Bianchi, F.T.; Molineris, I.; Mounce, B.C.; Berto, G.E.; Rak, M.; Lebon, S.; Aubry, L.; Tocco, C.; Gai, M.; et al. ZIKA virus elicits P53 activation and genotoxic stress in human neural progenitors similar to mutations involved in severe forms of genetic microcephaly and p53. Cell Death Dis. 2017, 8, e2567. [CrossRef] [PubMed]

46. Meistelman, C.; Agoston, S.; Kersten, U.W.; Saint-Maurice, C.; Bencini, A.F.; Loose, J.P. Pharmacokinetics and pharmacodynamics of vecuronium and pancuronium in anesthetized children. Anesth. Analg. 1986, 65, 1319-1323. [CrossRef] [PubMed]

47. Sampson, B.A.; Ambrosi, C.; Charlot, A.; Reiber, K.; Veress, J.F.; Armbrustmacher, V. The pathology of human West Nile Virus infection. Hum. Pathol. 2000, 31, 527-531. [CrossRef] [PubMed]

48. Yang, M.R.; Lee, S.R.; Oh, W.; Lee, E.W.; Yeh, J.Y.; Nah, J.J.; Joo, Y.S.; Shin, J.; Lee, H.W.; Pyo, S.; et al. West Nile virus capsid protein induces p53-mediated apoptosis via the sequestration of HDM2 to the nucleolus. Cell Microbiol. 2008, 10, 165-176. [CrossRef] [PubMed]

49. Smith, D.J.; Lapedes, A.S.; de Jong, J.C.; Bestebroer, T.M.; Rimmelzwaan, G.F.; Osterhaus, A.D.; Fouchier, R.A. Mapping the antigenic and genetic evolution of influenza virus. Science 2004, 305, 371-376. [CrossRef] [PubMed] 
50. Wurzer, W.J.; Planz, O.; Ehrhardt, C.; Giner, M.; Silberzahn, T.; Pleschka, S.; Ludwig, S. Caspase 3 activation is essential for efficient influenza virus propagation. EMBO J. 2003, 22, 2717-2728. [CrossRef] [PubMed]

51. McLean, J.E.; Datan, E.; Matassov, D.; Zakeri, Z.F. Lack of Bax prevents influenza A virus-induced apoptosis and causes diminished viral replication. J. Virol. 2009, 83, 8233-8246. [CrossRef] [PubMed]

52. Turpin, E.; Luke, K.; Jones, J.; Tumpey, T.; Konan, K.; Schultz-Cherry, S. Influenza virus infection increases p53 activity: Role of p53 in cell death and viral replication. J. Virol. 2005, 79, 8802-8811. [CrossRef] [PubMed]

53. Shen, Y.; Wang, X.; Guo, L.; Qiu, Y.; Li, X.; Yu, H.; Xiang, H.; Tong, G.; Ma, Z. Influenza A virus induces p53 accumulation in a biphasic pattern. Biochem. Biophys. Res. Commun. 2009, 382, 331-335. [CrossRef] [PubMed]

54. Wang, X.; Deng, X.; Yan, W.; Zhu, Z.; Shen, Y.; Qiu, Y.; Shi, Z.; Shao, D.; Wei, J.; Xia, X.; et al. Stabilization of p53 in influenza A virus-infected cells is associated with compromised MDM2-mediated ubiquitination of p53. J. Biol. Chem. 2012, 287, 18366-18375. [CrossRef] [PubMed]

55. Nailwal, H.; Sharma, S.; Mayank, A.K.; Lal, S.K. The nucleoprotein of influenza A virus induces p53 signaling and apoptosis via attenuation of host ubiquitin ligase RNF43. Cell Death Dis. 2015, 6, e1768. [CrossRef] [PubMed]

56. Yan, W.; Wei, J.; Deng, X.; Shi, Z.; Zhu, Z.; Shao, D.; Li, B.; Wang, S.; Tong, G.; Ma, Z. Transcriptional analysis of immune-related gene expression in p53-deficient mice with increased susceptibility to influenza A virus infection. BMC Med. Genom. 2015, 8, 52. [CrossRef] [PubMed]

57. Zhu, Z.; Yang, Y.; Wei, J.; Shao, D.; Shi, Z.; Li, B.; Liu, K.; Qiu, Y.; Zheng, H.; Ma, Z. Type I interferon-mediated immune response against influenza A virus is attenuated in the absence of p53. Biochem. Biophys. Res. Commun. 2014, 454, 189-195. [CrossRef] [PubMed]

58. Munoz-Fontela, C.; Pazos, M.; Delgado, I.; Murk, W.; Mungamuri, S.K.; Lee, S.W.; Garcia-Sastre, A.; Moran, T.M.; Aaronson, S.A. p53 serves as a host antiviral factor that enhances innate and adaptive immune responses to influenza A virus. J. Immunol. 2011, 187, 6428-6436. [CrossRef] [PubMed]

59. Hewitt, E.W. The MHC class I antigen presentation pathway: Strategies for viral immune evasion. Immunology 2003, 110, 163-169. [CrossRef] [PubMed]

60. Wang, B.; Niu, D.; Lai, L.; Ren, E.C. p53 increases MHC class I expression by upregulating the endoplasmic reticulum aminopeptidase ERAP1. Nat. Commun. 2013, 4, 2359. [CrossRef] [PubMed]

61. Fauci, A.S. Multifactorial nature of human immunodeficiency virus disease: Implications for therapy. Science 1993, 262, 1011-1018. [CrossRef] [PubMed]

62. Greenway, A.L.; McPhee, D.A.; Allen, K.; Johnstone, R.; Holloway, G.; Mills, J.; Azad, A.; Sankovich, S.; Lambert, P. Human immunodeficiency virus type 1 Nef binds to tumor suppressor p53 and protects cells against p53-mediated apoptosis. J. Virol. 2002, 76, 2692-2702. [CrossRef] [PubMed]

63. Duan, L.; Ozaki, I.; Oakes, J.W.; Taylor, J.P.; Khalili, K.; Pomerantz, R.J. The tumor suppressor protein p53 strongly alters human immunodeficiency virus type 1 replication. J. Virol. 1994, 68, 4302-4313. [PubMed]

64. Thakur, B.K.; Chandra, A.; Dittrich, T.; Welte, K.; Chandra, P. Inhibition of SIRT1 by HIV-1 viral protein Tat results in activation of p53 pathway. Biochem. Biophys. Res. Commun. 2012, 424, 245-250. [CrossRef] [PubMed]

65. Izumi, T.; Io, K.; Matsui, M.; Shirakawa, K.; Shinohara, M.; Nagai, Y.; Kawahara, M.; Kobayashi, M.; Kondoh, H.; Misawa, N.; et al. HIV-1 viral infectivity factor interacts with TP53 to induce G2 cell cycle arrest and positively regulate viral replication. Proc. Natl. Acad. Sci. USA 2010, 107, 20798-20803. [CrossRef] [PubMed]

66. Sawaya, B.E.; Khalili, K.; Mercer, W.E.; Denisova, L.; Amini, S. Cooperative actions of HIV-1 Vpr and p53 modulate viral gene transcription. J. Biol. Chem. 1998, 273, 20052-20057. [CrossRef] [PubMed]

67. Mukerjee, R.; Claudio, P.P.; Chang, J.R.; Del Valle, L.; Sawaya, B.E. Transcriptional regulation of HIV-1 gene expression by p53. Cell Cycle 2010, 9, 4569-4578. [CrossRef] [PubMed]

68. Boehmer, P.E.; Lehman, I.R. Herpes simplex virus DNA replication. Annu. Rev. Biochem. 1997, 66, 347-384. [CrossRef] [PubMed]

69. Maruzuru, Y.; Fujii, H.; Oyama, M.; Kozuka-Hata, H.; Kato, A.; Kawaguchi, Y. Roles of p53 in herpes simplex virus 1 replication. J. Virol. 2013, 87, 9323-9332. [CrossRef] [PubMed]

70. Maruzuru, Y.; Koyanagi, N.; Takemura, N.; Uematsu, S.; Matsubara, D.; Suzuki, Y.; Arii, J.; Kato, A.; Kawaguchi, Y. p53 Is a Host Cell Regulator during Herpes Simplex Encephalitis. J. Virol. 2016, 90, 6738-6745. [CrossRef] [PubMed] 
71. Rajcani, J.; Durmanova, V. Early expression of herpes simplex virus (HSV) proteins and reactivation of latent infection. Folia Microbiol. 2000, 45, 7-28. [CrossRef]

72. Hsieh, J.C.; Kuta, R.; Armour, C.R.; Boehmer, P.E. Identification of two novel functional p53 responsive elements in the herpes simplex virus-1 genome. Virology 2014, 460-461, 45-54. [CrossRef] [PubMed]

73. Munoz-Fontela, C.; Garcia, M.A.; Garcia-Cao, I.; Collado, M.; Arroyo, J.; Esteban, M.; Serrano, M.; Rivas, C. Resistance to viral infection of super p53 mice. Oncogene 2005, 24, 3059-3062. [CrossRef] [PubMed]

74. Biktasova, A.; Hajek, M.; Sewell, A.; Gary, C.; Bellinger, G.; Deshpande, H.A.; Bhatia, A.; Burtness, B.; Judson, B.; Mehra, S.; et al. Demethylation Therapy as a Targeted Treatment for Human Papillomavirus-Associated Head and Neck Cancer. Clin. Cancer Res. 2017, 23, 7276-7287. [CrossRef] [PubMed]

75. Shin, Y.; Lim, H.; Choi, B.S.; Kim, K.C.; Kang, C.; Bae, Y.S.; Yoon, C.H. Highly activated p53 contributes to selectively increased apoptosis of latently HIV-1 infected cells upon treatment of anticancer drugs. Virol. J. 2016, 13, 141. [CrossRef] [PubMed]

76. Munoz-Fontela, C.; Mandinova, A.; Aaronson, S.A.; Lee, S.W. Emerging roles of p53 and other tumour-suppressor genes in immune regulation. Nat. Rev. Immunol. 2016, 16, 741-750. [CrossRef] [PubMed]

77. Rivas, C.; Aaronson, S.A.; Munoz-Fontela, C. Dual Role of p53 in Innate Antiviral Immunity. Viruses 2010, 2, 298-313. [CrossRef] [PubMed]

(C) 2018 by the authors. Licensee MDPI, Basel, Switzerland. This article is an open access article distributed under the terms and conditions of the Creative Commons Attribution (CC BY) license (http:/ / creativecommons.org/licenses/by/4.0/). 